\title{
PROPHETS, PRIESTS, AND KINGS TODAY? THEOLOGICAL AND PRACTICAL PROBLEMS WITH THE USE OF THE MUNUS TRIPLEX AS A LEADERSHIP TYPOLOGY
}

\author{
Timothy PAUl JONES*
}

Southern Baptist Theological Seminary

\begin{abstract}
It has become widespread, not only among pastors and conference speakers but also among scholars such as Vern Poythress and John Frame, to utilize the threefold offices of Christ as a typology for church leadership. According to this application of the threefold office, different church leaders possess prophetic, priestly, and kingly capacities in differing degrees, and the most appropriate role for each leader depends on which of these capacities happens to be strongest. According to some proponents, the offices of prophet, priest, and king function as leadership personality types, with prophets identified as those leaders who are gifted as teachers, priests as those who care for people's needs, and kings as planners and organizers. This article undertakes an exploration of these three leadership roles and contends that, though the munus triplex itself is a venerable and biblical structure, the appropriation of prophet, priest, and king as typological categories for church leadership is not. Through examination both of relevant Old Testament texts and of New Testament appropriations of these offices of leadership, it is demonstrated that the typological categorization of leaders as prophets, priests, or kings falls far short when it comes to biblical support. Particularly absent in Scripture is any clear identification of these offices with specific traits that different church leaders possess in differing degrees. Kingship and priesthood in particular are not individualized traits but a communal identity, shared by the whole people of God and grounded in union with Christ
\end{abstract}

KEYWORDS: munus triplex, priest, prophet, king, multiperspectivalism

\section{Introduction}

'Touch not mine anointed'. That's what this book says!' the preacher stormed, flapping his Bible above his head. 'There are people in this church right now who are trying to touch God's anointed-but I won't let them stretch their hands against me!' I was fourteen years old, and common 
sense was in short supply for me at the time. Still, something about the chapel sermon that day in this tiny fundamentalist school didn't seem right. The chapel preacher for the day was the school principal, who also happened to be the church's associate pastor. The trouble had started when this principal and associate pastor was caught secretly watching high school girls as they changed clothes before gym class. It soon became apparent that this may not have been all that he was doing with girls in the church and school.

This day's chapel message was the principal's retort to those who wanted to terminate his employment and to report his crimes. His message began with David's refusal to overthrow King Saul. 'Who can stretch forth his hand against the LORD's anointed?' was what David had said (1 Samuel 26:9 KJV), and the principal identified himself as a man anointed by the Lord to be a pastor. Before it was over, the principal had made his way to Psalm 105:15 and declared that, because God had anointed him, God would punish anyone who tried to remove him from his leadership position.

At the time, I was far from able to articulate all the problems with the principal's interpretative acrobatics. Yet it occurred to me even as a follyprone fourteen-year-old that the associate pastor of a church was not precisely analogous to the anointed leader of Israel. Nevertheless, instead of confronting his sin and reporting his crimes, the congregation did nothing. In the end, he was hired by another church and school about forty miles away. 'Abusive church leaders often distort their role and authority by claiming to speak for God. This type of environment provides no accountability for those in leadership... Such environments produce parishioners (adults and children) who are initially unwilling to report criminal behavior and are uncooperative with criminal investigations' (Vieth \& Tchividjian 2015).

Perhaps it was this past experience with an abusive church leader who claimed an anointed role that triggered my queasiness when I began to hear seminary students use terms like 'kingly leaders' or 'priestly types' to refer to themselves. 'I'm not really preparing to do pastoral care', one of them commented to me over lunch at a conference, 'I'm more a king than a priest, you know. So someone else will need to do the counseling and visiting when I'm a pastor'. Another pastor-in-training put it this way: 'I'm more of a prophetic teacher, so I'm looking for a kingly type to supplement my leadership style by taking care of the church's strategy and vision'. Church planters in particular seemed eager to pigeonhole themselves and their fellow leaders into anointed categories of prophet, priest, or king.

When I pressed these individuals further, I realized they were operating with a leadership model that they perceived to be well-grounded in the Scriptures. From the perspective of these students, to lead like Jesus was to imitate one or more of the Old Testament offices that Jesus fulfilled. As they 
saw it, the threefold office of prophet, priest, and king provided a typology for church leadership, and every church leader possessed prophetic, priestly, or kingly gifts in differing degrees.

When I began to explore the foundations of this perspective on leadership, I confronted some of the same questions that had crossed my mind as a fourteen-year-old in that chapel service. How should leadership offices in ancient Israel shape leadership in the New Testament church-or should they? Does Old Testament kingship or priesthood connect at all with practices of pastoral leadership today? If so, how?

\section{Prophet, Priest, and King - a Typology for Christian Leadership?}

The perspective represented by the students who were eagerly classifying one another as prophets, priests, or kings connects each anointed role in ancient Israel with a type of church leader. Those with strong teaching gifts are considered prophets; counselors and caregivers are classified as priests; those who can lead organizations effectively are identified as kings. One application of this perspective specifically ties prophecy to the work of the church's teaching elders, while priesthood is linked to deacons and kingly functions are correlated with the church's ruling eldership (Frame 2008; Poythress 1996: 73-75).

According to this way of thinking, different church leaders possess prophetic, priestly, and kingly capacities in differing degrees, and the most appropriate role for each leader depends on which of these capacities happens to be strongest. Building on this typology, one pastor and conference speaker has promoted the three offices as leadership personality types, identifying prophets as those leaders who are gifted as teachers, priests as those who care for people's needs, and kings as planners and organizers (Goodmanson 2006; Goodmanson 2008; Fairchild 2008). Counseling professor Dan Allender similarly suggests that every church leader has 'skills and gifts that place' him or her 'primarily in one category-prophet, priest, or king'. Even as Allender treats these clustered sets of skills as inevitable, he does not expect that any Christian leader should stay in a single category. Unlike many who treat the triad as a leadership typology, Allender urges leaders to develop the capacity to lead from all three vantage points. 'We are to be all three, all at once', he writes. 'To lead is to mirror Jesus in all three of these capacities' (Allender 2006: 186-187). Although I would still suggest that Allender's application of the munus triplex to church leaders lacks sufficient biblical support, it represents a wiser and more balanced appropriation than many others due to his clear recognition that leaders should not remain within a particular leadership type.

Vern Poythress further suggests that 'all the gifts mentioned in Romans 12, 1 Corinthians 12, and Ephesians 4 can be roughly classified as prophet- 
ic, kingly, or priestly'. While not disputing that these gifts 'can be' classified as prophetic, kingly, or priestly, I question whether they should be so classified and particularly whether such classifications can be derived exegetically from the roles themselves or from the lists of spiritual gifts. When applied to spiritual gifts, the categories into which each gift might fit seem to me to overlap significantly, and a threefold division of gifts seems to be imposed on the lists rather than emerging from careful exegesis of Paul's lists.

What biblical warrant is there then for clustering church leaders into categories of priest, prophet, or king?

What I will suggest in this article is that, though the threefold office (munus triplex) itself is a venerable and biblical structure, the appropriation of prophet, priest, and king as a typology for church leadership is not. In fact, this usage of the munus triplex falls far short when it comes to support from Scripture. Particularly absent in Scripture is any clear identification of these offices with specific traits that different church leaders possess in differing degrees (See Timmis 2012: 34). I will look first at kingship in the Old Testament, then at the roles of priest and prophet, pointing out specific deficiencies in the identification of the three offices in the munus triplex as individualized capacities that different leaders exemplify to different degrees. My focus will be on the book of Deuteronomy; although I find a Mosaic origin for the book of Deuteronomy to be the most compelling explanation of the origins of the book, my argument does not depend on this assumption.

\section{Defining the Munus Triplex}

The munus triplex refers to the three Old Testament offices-prophet, priest, and king-that were fulfilled in the one person of Jesus. In the Old Testament, these offices represented roles that could involve anointing-an act that signified the empowerment of a specific individual for a divinelydesignated duty (Exodus 28:41; Leviticus 4:3-16; 6:22; 1 Samuel 12:3-5; 16:6, 13; 1 Kings 19:16). No later than the fourth century AD, Christians had already picked up on the triad of prophet, priest, and king. The church historian Eusebius of Caesarea (Eusebius 1:3:8) identified Jesus as 'the only High Priest of all, the only King of every creature, and the Father's only High Prophet of prophets' (See also Wainwright 1997: 110-112; Crouse 2015).

\section{The Contours of Kingship in Israel}

Yahweh promised in the Torah that he would provide everything his people might need to flourish in the land if only they would remain faithful to his covenant. And yet, a time would come when the people would no longer be satisfied with what Yahweh offered. They would demand a king to repre- 
sent them, to fight for them, and to become their judge so they could become 'like all the other nations' (1 Samuel 8:20; see also 12:12). The people's desire for a king was not a problem. Kingship had, in fact, been part of God's plan from the beginning (Genesis 17:6, 16; 35:11; Numbers 24:17) (See also, Diffey 2011: 313-316). The people's desire was not merely to have a king like other nations have but to set up a king in the same manner and for the same purposes as the nations around them.

Foreseeing the people's request, Moses mapped out a clear manifesto for Israel's monarchy. This design would indeed provide Israel with a kingbut the monarchy that Moses described would, in some sense, accomplish the opposite of what Israel would demand. In God's design for Israel, kingship would not be a status to be seized or a goal to be achieved for one's own benefit. Kingship would be a gift to be received in God's time by God's grace for the good of God's people. The result would be a monarchy that would make Israel unlike any other nation under heaven.

\section{A Son, Selected from among His Brothers}

In other nations, a king or priest might be seen as the son of a deity, divinely elevated above his subjects (See Pritchard 1969: 289; Levinson 2001: 512514). In Israel, however, the entire nation was God's son corporately, and everyone-including the king-was a brother (Exodus 4:22-23; 6:3-9; see also, Sirach 36:17). The position to which the king would be called was not sovereignty above or separate from the community of Israel but stewardship within the community in submission to God's Word. The king's responsibilities as a brother within the covenant community always superseded any power he might enjoy as a monarch over the covenant community.

\section{A Servant and a Student, Submitted to God's Word}

The priority of the king's exemplary faithfulness to the covenant is particularly clear in the prohibitions that Moses placed on future kings. The purpose of these prohibitions was to drive Israel to entrust their security to the faithfulness of Yahweh rather than relying on their own prosperity or political power (Block 2005: 263). The prohibitions given to kings were threefold:

1. The king 'must not acquire many horses for himself'. 'Although Anatolia was the primary source of horses for trading purposes, the residents of Palestine would normally turn to Egypt as the main source of supply' (Craigie 1976:255). The clause 'send the people back' may refer to sending Israelites as slaves to purchase horses and probably either explains the prohibition on horse-trading with Egypt ('otherwise he might send people back to Egypt for this purpose') or qualifies the 
prohibition ('especially not to the point that he would send people back to Egypt') (Tigay 1996: 167). Yahweh had promised his people would never see the Egyptians again (Exodus 14:13; Deuteronomy 28:68); to return to Egypt willingly would be to nullify Yahweh's promise.

2. The king 'must not acquire many wives for himself'. This is not to suggest that this text only disallowed marriage alliances with pagan nations or that only marriage alliances were in view; Moses clearly saw a large harem as incompatible with Israelite kingship, regardless of the purpose of the marriages. According to 11QTemple 57:17-18, this prohibition limited the king to one wife, though this interpretation of the text was not universally accepted.

3. The king 'must not acquire very large amounts of silver and gold for himself'. Part of the reason for the division of the kingdom after the death of King Solomon may have been Solomon's disproportionate imposition on the northern kingdom of responsibilities for the support of the royal court and the army (1 Kings 4:7-28) (for further discussion, see Sweeney 2007: 169-170).

And yet, there was one item that he was specifically commanded to make 'for himself'. The king was called to 'write for himself a copy of this law on a scroll in the presence of the Levitical priests' (Deuteronomy 17:18 NASB). By copying the covenant anew, each king of Israel would engage in a sacred act that would produce a sacred artifact. Through this act and artifact, every king of Israel would participate anew in Yahweh's covenant with Israel (see Kline 1997: 27-44). In kingdoms surrounding Israel, covenant documents might be kept in a temple so that a priest could read the treaty to the king at designated times. Statements of deposition may be found in several surviving Hittite treaties: 'A duplicate of this tablet is deposited before the SunGoddess of Arinna since the Sun-Goddess of Arinna governs kingship and queenship', reads one such document. 'A duplicate of this tablet is deposited in the land of Mittani before the Storm-God', another text declares. 'It shall be read repeatedly forever and ever, before the king of the land' (for these and other examples, see Beckman 1996: 42-48). Moses prescribed a similar practice for Israel each year at the Feast of Tabernacles (Deuteronomy 31:913) in addition to the requirement that the king copy and keep a copy of the Torah; however, Moses called for a reading of the Torah not merely in the hearing of Israel's leaders but in the presence of everyone in Israel ('men, women, children, and foreigners').

This personal copy of the covenant would serve as a working document to direct every judgment that the king handed down. The same words that once thundered from the peak of Mount Sinai would rest at king's finger- 
tips to mold his life and his leadership. The result would be a leader who feared God, submitted to God's instruction, enacted God's statutes, and taught his sons to do the same (17:19-20).

\section{The Rise and Fall of Israel's Kings}

In some sense, Israel's monarchy began to fall short of God's standard before God had even selected their first king. In the era of the judges, the people begged Gideon the judge to take the office of monarch, but Gideon refused (Judges 8:23). Gideon's son Abimelech was neither appointed by God nor anointed by a prophet or priest, yet he claimed for himself the office that his father had refused (Judges 9:2). This pretender king's reign ended when a woman rolled a millstone from the top of a tower and crushed his skull (Judges 9:53-54; compare Genesis 3:15). Later Israelites never viewed Abimelech as a legitimate monarch—but the authors of the Old Testament did draw from the successes and shortfallings of Gideon and Abimelech to make sense of the reigns of later kings. (See Leithart 2003, Kindle locations 1768-1772, 2530-2533, 3039, 3051-3065, 3934).

Israel's first true monarch was Saul the son of Kish. Saul was a tall and handsome warrior from a wealthy family (1 Samuel 9:1-2)—but this impressive ruler repeatedly claimed sovereignty by bypassing Yahweh's commands. When Yahweh's prophet confronted his rebellion, Saul's initial response in every instance was an excuse (1 Samuel 13:8-15; 15:1-21). It wasn't long before Yahweh raised up a shepherd boy to take Saul's place. This shepherd and his descendants would become 'the true successors of the judges' (McCarthy 1965: 133).

David the shepherd king stole the hearts of the people and became a man after the heart of God (1 Samuel 13:14; 1 Chronicles 12:38). His reign set the standard for every future monarchy, and God promised an endless dynasty for one of his descendants (2 Samuel 7:12-16; 1 Kings 15:3-5, 11; 2 Kings $14: 3 ; 16: 2 ; 18: 3 ; 22: 2$ ). Yet David also multiplied wives for himself and stole the spouse of one of his most loyal subjects (1 Samuel 25:42-44; 2 Samuel 5:13-16; 11:1-21; 1 Chronicles 3:1-9). Unlike Saul, David repented without hesitation when confronted (2 Samuel 12:7-15; Psalm 51)—but not even the king's heartfelt repentance could keep his sons from following in his footsteps. One of David's sons raped his own half-sister (2 Samuel 13:122). Another son tried to steal his father's kingdom and, in the process, stole his concubines as well (2 Samuel 15:1-6; 16:15-23).

Solomon, the heir of David's throne, became known far and wide as the wisest judge and king in his day (1 Kings 3:9, 16-28; 7:7). Yet King Solomon also defied God's design for kingship. He hoarded silver and gold for himself, married hundreds of women, and traded for horses from Egypt and Kue (1 Kings 3:1-2; 4:26-28; 10:14-11:3). The result was a heart that wan- 
dered from God's commands and a burden of taxation and labor that his people could not bear (1 Kings 11:4-8; 12:4). Solomon's body had barely stiffened in the tomb before his kingdom was torn in two (1 Kings 12:1220). In the centuries that followed Solomon's demise, neither kings nor judges were able to maintain lasting justice in either kingdom (Isaiah 1:23; Jeremiah 5:28; Ezekiel 45:9; Micah 3:1, 9; 7:3). Yet God never gave up on his design for a perfect king-for a king who would judge with justice, depend on God's power, and submit to God's Torah. Such a king would stand as a model of life lived in covenant with God. And yet, such a monarchy seemed to stand beyond any human capacity. The world needed a judge and king whose every verdict was faithful and true, but-thus far-every human judge and king had failed.

\section{The Return of the King}

It was in the virgin womb of a girl from Galilee that the consummate fulfillment of kingship began to blossom into the fullness that God had always intended (Luke 1:32-33). God himself entered the cosmos in the flesh of Jesus Christ to do what no previous king had done or could do: he upheld every covenant of God and inaugurated a 'kingdom not of this world' to provide a foretaste of perfect justice on the face of a fallen earth (John 18:36). From the womb of Mary to the garden tomb and beyond, Jesus Christ followed every detail of God's design for kingship. He submitted to his Father's Word, rejected every trapping of earthly power, and refused to exalt himself above his brothers (John 5:19-20; 8:54; 18:36). He was a king who came proclaiming a kingdom (Matthew 4:23; Mark 1:15; Luke 4:43), and he will come again to multiply this kingdom around the globe until the earth is 'filled with the knowledge of the LORD's glory, as the waters cover the sea' (Habakkuk 2:14).

\section{Kingly Leadership in the New Covenant}

In light of what we've learned about kings in the old covenant, how should this kingship shape the leadership of God's new covenant people? According to those who treat kingship as a typology for a particular kind of church leader, kingly leaders are visionary builders who develop organizational strategies and take responsibility for the church's direction. 'Ultimately'one proponent of this typological approach claims-'large ministry areas must be led by a king' because kingly leaders are the ones who actually get jobs done (Driscoll 2008: 68). Another proponent of this approach specifically urges 'upper-echelon leaders of complex organizations' to live as kingly leaders, emulating the template for Old Testament kings (Cafferky 2010:33). In a bizarre moralization of Deuteronomy 17:17, the biblical command not to 'acquire many wives' becomes in this article the 'principle 
of structurally minimizing the interorganizational entanglements... when upper-echelon leaders participate in interlocking directorates' (Cafferky 2010: 45).

Scripture, however, does not describe kingship in terms of visionary leadership or strategic skills. Neither in Moses's description of God's design nor in later depictions of the ideal king is there any hint that visionary organizational strategies were part of the job description for kings in Israel. Even if we suppose that kingship is a type of leadership that can be conveyed to particular individuals in the church, the definition of a kingly leader as a dominant visionary strategist is unbalanced at best and fundamentally flawed at worst. Treating kingly leadership as visionary organizational strategy imports a very modern concept of leadership into old covenant kingship and, in the process, skews our understanding of church leadership in the new covenant.

This is not to suggest that visionary strategies are unhelpful or unnecessary in leadership! The point is that Scripture never links these capacities to the office of king or even to a particular role in the church. Kingship in the old covenant was focused primarily on modeling covenant faithfulness and judging the people in righteousness, not on visionary leadership or strategic planning.

Even more problematic for the claim that kingly leadership is conveyed to particular individuals in the church is the fact that kingship in the new covenant is never identified as the property of individual Christians. Kingship in the kingdom of God is ascribed to God in Christ and to the whole people of God in union with Christ. Jesus promised his first disciples that they would reign alongside him (Matthew 19:28; Luke 22:30). But this glorious privilege extended far beyond the apostles! 'If we endure, we'-Paul wrote to Timothy, referring to all of God's people-'will also reign with him' (2 Timothy 2:12; see also 1 Peter 2:9; Revelation 20:4-6). Through union with Christ, every believer in Christ participates in the kingship of Christ, but this participation is corporate and communal, not individual.

None of us is called to live as a kingly leader individually or independently in the church of Jesus Christ. When a few Christians in Corinth began to act like royalty in a manner that separated them from their fellow believers, Paul called them to return to unity with the body. 'You have begun to reign as kings without us', Paul declared with a generous dollop of sarcasm, 'and I wish you did reign, so that we could also reign with you!' (1 Corinthians 4:8). Instead of claiming a kingly role over the Corinthians, Paul called them to imitate his pattern of living as a servant of Christ and a manager of God's mysteries (1 Corinthians 4:1, 16). This is not to suggest that the kingliness claimed by this faction in the Corinthian church was the same as the kingly leadership proposed by those who see prophet, priest, 
king, and judge as typological categories for church leaders. It is simply to point out that, when the imagery of kingship was applied to particular persons in the church separate from others, the imagery was being used negatively to call church members to return to unity with the corporate body, awaiting the full revelation of their kingship in union with Christ at the end of time. The foundations of the Corinthians' pretensions of kingship probably had to do with their over-realized eschatology (see Thiselton 2000: 357358).

\section{Kingship as Proleptic Participation in a Judgment That Is Yet to Come}

So, if kingly leadership isn't an individual capacity for organizational effectiveness and strategic vision, what is it? The ideal king in the Old Testament was an exemplar of covenant faithfulness who judged his people according to God's Word. When Jesus told the apostles that those who remained with him would also reign alongside him, he tied this reign to participation in the judgment of God's people (Matthew 19:28; Luke 22:28-30). When the saints were enthroned in John's heavenly vision, they were 'given authority to judge' (Revelation 20:4). It seems, then, that one of the primary expressions of our union with Christ the King will be participation in his judgment at the end of time. And yet, our participation in this future judgment will not wait until the end of time. The church's participation begins in the present. Whenever God's people join together in the holy work of church discipline, we participate in the very judgments of God.

When Christ returns and reigns at the end of the age, all those united with him will join him in judging the cosmos (1 Corinthians 6:1-11; Revelation 20:4). 'Christ alone will be the sovereign and will yield his kingship to [the Father]... and arguably... the corporeity of believers characterized by being-in-Christ in this derivative sense share in Christ's acts and declarative speech-acts' (Thiselton 2000: 431). Whenever we engage in church discipline, we rehearse this future prospect by staging a small play that pictures the great judgment that is yet to come (Leeman 2012: 33). This proleptic participation in God's future judgment is not merely symbolic; neither is it accomplished fully in the church's present pursuit of justice. It is an actual-albeit incomplete-participation in God's future judgment, made possible through our union with the one whom God has appointed to enact justice in his world.

\section{Priesthood and Prophecy in Israel}

We turn now from the office of king to the offices of priest and prophet. Scholars and church leaders who treat the offices of Christ as a typology for church leadership typically link priesthood with caregiving and prophecy with teaching. According to this categorization, priestly leaders provide per- 
sonal care for God's people, in contrast to prophets who proclaim and protect the Scriptures. Priests are masters at resolving conflicts and caring for the vulnerable. Prophets, on the other hand, excel at 'vision, study, preaching, teaching, doctrinal truth, refuting error, and calling people to repent' (Driscoll 2008: 67; Goodmanson 2006; Goodmanson 2008). The priestly leader's concern is-Goodmanson adds-who might be 'hurt by the circumstance. Often they will avoid the sauthority or the way it is should be implemented if it causes too much emotional damage... A priest has a tremendous understanding of the needs of the people'. Some have pressed the point further and identified the church's priestly ministry with the work of deacons, while assigning prophetic ministry to the church's teaching pastors (Frame 2008). I will argue, however, that-though the offices of prophet and priest are relevant for new covenant leaders-their relevance is not as typological categories that describe particular skill sets in the lives of certain leaders.

\section{Priests as Guardians and Teachers of God's Word}

Whenever a judge faced a complex case, the judicial process would pass to a judge and to priests convened in the place of God's choosing (Deuteronomy 17:8). After hearing the details of the difficult case, the judge and priests would hand down a final verdict (17:9). The clause could be translated 'the priests who are Levites or the judge' (Deuteronomy 17:9), indicating that either priests or a judge could hand down a decision. However, 'it is likely that referred cases were dealt with in the central tribunal by both priests and judges' (Craigie 1976: 252). 'While [17:9] speaks of priests in the plural, [17:12] refers to the priest in the singular. So while priests may be involved in the process, the final decision belongs to the chief judge and high priest' (Fernando 2012: 443). The role of an additional judge in such cases seems clear-the judges undertook a careful investigation, weighing evidences anew and analyzing the testimony of the accusers (see Deuteronomy 19:18). But what about the priests?

Based on the priestly roles described throughout the rest of the Old Testament, it seems that the primary responsibility of priests in disputed legal cases may have been to teach and to apply precepts found in the Torah. 'Priests were educated, with civil and criminal law forming part of their knowledge. According to [Deuteronomy 17:18] and 31:9 and 24, they have charge of the scroll of God's teaching, and according to Leviticus 10:11, their tasks include teaching the people all of God's laws' (Tigay 2003: 164; see also: Tidball 1986: 42). Judges investigated evidence and searched for the truth about the crime; priests searched the Torah and declared verdicts on the basis of the written Word of God. 
Priests were consecrated to bless the people, to represent the people, and to offer sacrifices for the people (Exodus 28:9-12; Leviticus 4-16; Numbers 6:22-27). God also, however, commanded the descendants of Aaron to teach his written revelation-and this responsibility extended far beyond a priestly proclamation in difficult legal cases. From the earliest stages of Israel's history as a nation, the role of teaching 'all the statutes that the LORD has given' was central to the priesthood (Leviticus 10:11). 'The priest was also a teacher, and in the first place a teacher of the law' (Blenkinsopp 1995: 82). One might say that Leviticus 10:10-11 provides a job description for the priesthood: 'You must distinguish between the holy and the common, and the clean and the unclean, and teach the Israelites all the statutes that the Lord has given to them through Moses' (Stevens 2012: 82). In Deuteronomy, priests were assigned the privileges of instructing the people in the Torah, safeguarding the scrolls that contained God's written revelation, and superintending the copying of these scrolls (Deuteronomy 17:18; 31:9-13; 33:10). Not only in Israel but also in Ancient Near Eastern contexts beyond Israel, the priests who maintained temples to the people's gods were also responsible for maintaining documentation of covenants. See, for example, the treaty between Šuppiluliumas and Mattiwaza of Mitanni: 'A duplicate of this tablet has been deposited before the Sun-goddess of Arinna, because the Sun-goddess of Arinna regulates kingship and queenship. In the Mitanni land [a duplicate] has been deposited before Tessub, the lord of the [shrine] of Kahat. At regular intervals shall they read it in the presence of the king of the Mitanni land and in the presence of the sons of the Hurri country' (Pritchard 1969: 205; see also Block 2005: 271). Priests were not merely mediators of God's blessings or representatives of God's people; the priests and their Levitical compatriots were also expositors and custodians of God's written Word.

Although the teaching role of priests would be particularly important in the place chosen for God's tabernacle, the teaching responsibilities of the priests were not limited to this single locale. By divine design, priests and Levites possessed no unified territory. Instead, priests and Levites were distributed throughout the land so that the Torah might be taught in every place. Centuries earlier, the patriarch Jacob had predicted on his deathbed that, due to the bloodlust he had glimpsed in his son Levi, Levi's descendants would be scattered throughout the land (Genesis 49:5-7). Later, the family of Aaron within the tribe of Levi was selected to serve as Israel's priesthood and the entire tribe of Levi received the responsibility of assisting the priesthood (Exodus 28:1-5; 32:26-39; Numbers 1:47-53), but Jacob's words were still fulfilled. Before the people crossed into Canaan, Yahweh commanded the Israelites to set aside four dozen villages, scattered throughout the land, as the property of priests and Levites (Numbers 35:1- 
8). Through this scattering of the Levites, Jacob's curse on the descendants of one of his sons became a blessing for the descendants of all his sons. The Levites' lands were limited to a narrow tract that skirted each of their scattered villages, but the Levites received a far greater provision than vast fields and pastures. Yahweh's 'fire offerings' - and, ultimately, Yahweh himself-became the inheritance of the tribe of Levi (Deuteronomy 18:1-2; see also Numbers 18:20-24). The sovereign Lord was the Levites' allotment, and they lived as guests at his table. 'The designations the ppriests', the <Levites', and the «whole tribe of Levi indicate that the priests and Levites were not always coextensive terms; the priests> were those Levites who were the descendants of Aaron, and the Levites included all those who belonged to the tribe of Levi, whether or not they were descendants of Aaron (Numbers 18:20, 23-24)' (Kalland 1992: 118). Whenever offerings were brought to Yahweh, the priests and Levites received produce from their fields and specified portions from the sacrifices of cattle, oxen, and sheep (Deuteronomy 18:3-4). If the people failed to worship Yahweh at the place of his choosing, the priests and Levites could not continue to serve at Yahweh's altar; the livelihood of the tribe of Levi depended, therefore, on the covenant faithfulness of all the tribes of Israel. Any ritual role that a priest possessed was relativized by his precedent identity as a follower and faithful teacher of God's Word.

In light of this emphasis, it seems that the judicial hearing before the priests and judges may have provided not only a courtroom where righteous judgments could be handed down but also a classroom where the people could be taught anew to remain faithful to their covenant with God. If expertise in the Torah was the purpose of the priest's presence in difficult legal cases, the verdicts that a righteous priest declared in these cases were never the priest's own opinion. His verdicts were the truth of God conveyed to the people of God through the exposition and application of the Word of God.

\section{The Failure of the Priests and Levites}

And yet, the priests did not remain faithful to their calling as teachers. During the reign of King Asa, the prophet Azariah pointed out that the people of Judah had already spent 'many years... without a teaching priest, and without instruction' (2 Chronicles 15:3). In the time of Isaiah, some priests were too drunk to distinguish injustice from justice, and the prophet mocked such priests, asking, 'Who is he trying to teach?' (Isaiah 28:9). Micah challenged the priests in his day because they demanded payment for their teachings (Micah 3:11). When the Assyrians settled pagan populations in Israel, wild beasts tormented the new inhabitants of the land until a priest was sent to teach 'how they should fear Yahweh' (2 Kings 17:24-28)— 
a phrase that seems to have suggested obedience to Torah (see parallels between fear of Yahweh and precepts of Torah in Psalms 112:1; 119:38, 63). 'Ancient Israel... could apprehend genuine wisdom and fear of the Lord by keeping and studying Torah... The fear of Yahweh reflects a loyal response to the covenant (Deuteronomy 6:2, 13, 24) and is closely identified with wisdom. It also designates observance of the Torah (Psalm 119:63; Ecclesiastes 12:13-14)' (Klouda 2000: 184). [My colleague Peter Gentry first pointed out to me the connection between obedience to Torah and the fear of the Lord.]

Whenever spiritual awakenings interrupted the people's downward spiral, renewed teaching from the priests and Levites typically accompanied the people's revived commitment to God's covenant (2 Chronicles 17:9; 35:3; Nehemiah 8:9)—but these renewals in the priesthood were shortlived. These many failures in the old covenant priesthood revealed the people's desperate need for an unfailing priest-for a priest who was 'holy, innocent, undefiled, separated from sinners, and exalted above the heavens' (Hebrews 7:26).

\section{Priestly Leadership and Prophetic Teaching in the New Covenant}

So what about the claim that prophecy and priesthood provide typologies for leadership in the new covenant community? In this typology for new covenant leadership, those who are skilled in caregiving are considered to be priestly leaders while teachers and preachers are prophetic leaders (See Covrig 2012: 40-41; Driscoll 2008: 67; Frame 2008; Goodmanson 2006; Goodmanson 2008; Poythress 1996: 73-75). When it comes to biblical and theological support, however, these linkages fall far short in at least two ways:

1. In the first place, teaching ministry was not identified primarily with prophets in the old covenant, and mercy ministry was not tied primarily to priests. The task of teaching was connected far more consistently to priests and Levites than to prophets (Leviticus 10:10-11; 2 Chronicles 15:3; 17:7-9; 35:3; Ezra 7:6, 10; Nehemiah 8:7-9; Isaiah 28:7-10; Jeremiah 18:18; Ezekiel 7:26; 22:26; Micah 3:11; Malachi 2:3-9). And so, even if old covenant offices of leadership happened to provide a legitimate typology for Christian leaders today, caregiving would not constitute the essence of priestly leadership. Yes, old covenant priests were representatives and intercessors. But the intercessory responsibilities of priests and Levites should not eclipse their instructional role. When Jesus taught the people during his time on earth, he was fulfilling the office of priest no less than the office of prophet. 
To be sure, proclamation was essential to the role of the prophet, but the identification of teaching leadership with prophetic leadership ignores essential components of both prophetic and priestly roles. In Scripture, prophets had a distinct relationship with God that resulted in efficacious prayer, and they spoke a message that was not their own (see, e.g., Genesis 20:7; Exodus 7:1-2; Deuteronomy 18:18). When the people acclaimed Jesus as a prophet, it was only rarely in response to his teachings and, even then, the words may have been perceived more as a prophetic oracle than as teaching or proclamation (John 7:37-44). Most often, the people's acclamations were in reaction to his miraculous signs or supernatural knowledge, again suggesting a weakness in the direct linkage between prophecy and teaching (Luke 7:11-17; John 4:16-20; 6:1-15; 9:17). John the Baptist was a prophet (Matthew 21:26; Mark 11:32; Luke 20:6) but he seems not to have been known for teaching apart from teaching his followers how to pray (Luke 11:1). Prophecy was expected to extend to all God's people at the dawning of a new messianic age (Joel 2:28-29; Acts 2:16-18; cf. Numbers 11:25-29). In the New Testament churches, prophecy and teaching did overlap (Acts 13:1) but the gifts were distinguished when listed (1 Corinthians 12:28-29; 14:6; Ephesians 4:11). (For overlap between prophecy and teaching in Acts 13:1, see Keener 2013: Kindle locations 24223-24237).

2. Furthermore, priestliness in the new covenant is primarily communal, not individual. In the new covenant community, priestliness is not an individualized quality but a communal identity, given to every believer in Jesus Christ.

The priesthood of all believers has an easy habit of becoming a discussion of the priesthood of each believer, individually and independently, in which each of us is considered our own priest. In that way, the doctrine falls victim to the very thing it seeks to avoid: individuals appropriate the very thing which in the work of Christ ends, and which is only continued as the believer participates in the body of Christ, in the whole life of the church. The priesthood of all believers is a doctrine that states that priesthood is no longer individual (whether in relation to ministers or the total number of individuals in the church), but corporate in the narrow sense of the term, relating to the body of Christ... [In the New Testament] the term hiereus is only ever used in the singular (with the exception of referring to temple priests) of one person, Jesus Christ' (Greggs 2015: 377).

Since no part of our priesthood depends on our own gifts or skills, no believer can possess a different essence or degree of priestliness in comparison with other believers. Laypeople in the new covenant are not merely Le- 
vitical servants who observe and obey a new order of priestly leaders. United with the high priest of an order far greater than Aaron's, all of God's new covenant people constitute a common priesthood (Hebrews 7:11-19; 1 Peter 2:4-9; Revelation 5:9-10).

Even if caregiving could be linked to priestliness, Scripture does not support the supposition that new covenant priesthood is a capacity that different individuals exemplify in differing degrees. Through faith in Christ, men and women from every race and nation are being bound together into a single multihued multitude of priestly ministers. The priesthood of the whole community provides direct access to Christ the great teacher and priest through his Spirit (John 13:13-14; 16:12-15; see also Jeremiah 31:33).

'Part of the newness of Jeremiah's covenant seems to be a democratization of the teaching office (from the least to the greatest in Israel) in the latter days so that every Israelite will be in the knowledgeable position of the priests (and likely also prophets) and thus will have no need to be taught by any leader or caste of priests... The likely reason for this democratization is that in the new age all will have more access to revelation than did even the teaching priests and prophets of the former age' (Beale 2011: 734-735).

No one in the body of Christ can become more priestly than we already are, because every aspect of Christ's priesthood has already become ours in him. The suggestion that certain church leaders might be more priestly than others calls to mind a couple of lines from a song by Larry Norman (1972): 'You say all men are equal, all men are brothers/Then why are the rich more equal than others?'-except that I would paraphrase my concern in this context as, 'You say all believers are priests, all believers are brothers/Then how can counselors and caregivers be more priestly than others?' My couplet lacks the poetic rhythm of Larry Norman's lyric, but perhaps it has other qualities that make up for that.

Even when Paul mentioned 'priestly duty' in connection with his unique calling as 'a minister... to the Gentiles' in his epistle to the Romans, he did not treat priestliness as a capacity that he experienced to a greater degree than other Christians (Romans 15:16 NIV). One other instance in which Paul drew a possible parallel between old covenant priests and new covenant church leaders was in his first letter to the Corinthians: 'Don't you know that those who perform the temple services eat food from the temple, and those who serve at the altar share in the offerings of the altar? In the same way, the Lord has commanded that those who preach the gospel should earn their living by the gospel' (1 Corinthians 9:13-14). However, this comparison is part of a sequence of similes that also includes references to soldiers, vinedressers, shepherds, and oxen (1 Corinthians 9:7-12). Paul was drawing examples from a wide range of familiar patterns wherein an 
individual was allowed to receive provisions from the goods gained through service. The reference to priesthood seems to be as applicable to a GrecoRoman pagan priesthood as to a Levitical priest in the old covenant. As such, it seems unlikely that this reference supports any individualized role as a priest or a priestly leader. (For further discussion of this text, see Thiselton 2000: 661-663, 691-692).

Earlier in the same epistle, Paul called all believers to participate in the priestly work of offering themselves 'as a living sacrifice, holy and pleasing to God' (12:1). Although 'bodies' is plural, 'sacrifice' is singular, suggesting a community united as one in Christ. N. T. Wright captures the sense well: 'Offer God the true worship; be transformed by having your minds renewed, because you should be thinking as one people in the Messiah' (Wright 2002; 708). 'In keeping with the rest of the New Testament, Paul assumes an eschatological transformation of the Old Testament cultic ministry in which animal sacrifices are replaced by obedient Christians (cf. Romans 12:1) and the praise they offer God (Hebrews 13:15)' (Moo 1996: 891). 'The terms hagian [holy] and euareston [acceptable] have cultic associations... The former term denotes the idea that the sacrifice is dedicated to God, while the latter evokes Old Testament notions of sacrifices that are pleasing and fragrant to God... The word latreian [service, worship] is another cultic term. What is remarkable is that Paul has applied the language of the cult to everyday existence' (Schreiner 1998: 644, 646). A few sentences after Paul described his own 'priestly duty', the apostle extended priestly terminology to all believers, using language of priestly ministry to describe the Gentile Christians' sacrificial giving for the sake of their Jewish brothers and sisters (15:27).

\section{New Covenant Priesthood as the Devoted Property of God}

What, then, is the point of new covenant priesthood? If priestly ministry isn't primarily caregiving and if priestliness is the shared identity of the entire community, what does it mean to be 'a royal priesthood'? And, most important for our purposes, how should Christian leaders lead in the context of a priesthood that includes every believer in Jesus Christ? Here's what I want to suggest and to show throughout the remainder of this article: When expanded to encompass all of God's people, the primary point of priesthood in both covenants was to highlight the holiness of God's people; this holiness is not primarily separation from the world but sacrificial devotion to God as his property and possession.

The author of placed the phrase 'kingdom of priests' parallel to 'holy nation', suggesting a link between priesthood and holiness (Exodus 19:6). Immediately after describing Israel as a priestly kingdom and a holy nation, God commanded both priests and people to be set apart as holy (Exodus 
19:6, 10, 22). In Exodus 19:22, Yahweh called for the consecration of a priesthood prior to the setting a part of the tribe of Levi or the establishment of the Aaronic priesthood. Some have taken this as an anachronism in which a redactor placed this text out of order (see Durham 1987: 272-273). A more likely suggestion, on the basis of Exodus 13:11-15, is that the firstborn son in each family functioned as a priest at this time (Kaiser 2008: 476). It is also conceivable that Yahweh was referring to the whole community as a priesthood or that certain persons in the Israelite community other than firstborn sons functioned in a priestly role prior to the establishment of the Aaronic priesthood, much like Melchizedek and Jethro in earlier times (Genesis 14:18; Exodus 2:16).

Centuries later, Simon Peter embedded his citation of this passage in the context of a call to holiness and covenant faithfulness. 'As the one who called you is holy, you also are to be holy in all your conduct; for it is written, 〈Be holy, because I am holy`, the apostle Peter wrote. A few verses later, Peter specifically identified God's people as 'a holy priesthood' in union with Christ: 'You yourselves, as living stones, are being built into a spiritual house for a holy priesthood to offer spiritual sacrifices acceptable to God through Jesus Christ' (1 Peter 1:15-16; 2:4-5; compare Leviticus 11:44-45; $19: 2 ; 20: 7)$. When extended to include all of God's people, priesthood seems to be primarily about holiness.

This holiness is not, however, mere separation from the world for the purpose of greater personal piety. 'Human holiness is not to be found in separation in the sense of withdrawal, and certainly not in moral prudishness, but in distinctiveness of lifestyle that does not eclipse compassionate and open-hearted reaching out to those who are not fit for God's presence' (Robson 2011: 146). Although Robson focuses on love as an overlooked dimension of holiness, he rightly emphasizes distinctiveness rather than separation as an overlooked component in the definition of holiness when applied to human beings. As French scholar Claude-Bernard Costecalde has demonstrated, the fundamental point of 'holiness' when applied to human beings in the Scriptures was not 'separation' but 'devotion' (Costecalde 1986: 137). Understood in this way, 'a holy priesthood' implies the sacrificial devotion of God's people as a possession of the living God. Through faith in Jesus Christ, we have been joined with a great high priest who was devoted to God's purposes to the point of death. United with the great high priest, we too have been designated as God's possession and consecrated for God's purposes (Romans 6:1-11). 'The priestly function of the whole people of God is to be holy and offer sacrifices to God, and only in that context to mediate between God and fallen humanity. Christians are to offer themselves in loyal consecration to God, [offering] spiritual sacrifices that are «coextensive with the lives of the faithful», by which the church <brings the 
kingdom of God into being here below' (Carson 2007: 1031; see also discussion in Jobes 2005: 161).

When we embrace our place as a devoted priesthood, we find ourselves reaching beyond the new covenant community to pursue justice and to proclaim the good news of God's kingdom in the world. We-in the words of Simon Peter-declare 'the praises of the One who called [us] out of darkness', and a door is opened for people from every social and ethnic background to 'glorify God' (1 Peter 2:9, 12). Paul made this same point in a different way when he referred to his proclamation of the gospel as a priestly service whereby believers from all nations were being devoted to God as a living sacrifice. God had called Paul to serve as a 'minister of Jesus Christ to the Gentiles, ministering the gospel of God, that the offering up of the Gentiles might be acceptable' (Romans 15:16 KJV; see also Isaiah 66:20-21; Romans 12:1-2; Hebrews 13:15). Because we are united with Christ the great high priest and sacrifice, we pursue justice and proclaim the gospel with boldness and sacrificial devotion, and God transforms the people around us into a devoted priesthood and living sacrifice as well [portions of this paper are adapted from the forthcoming book The God Who Goes Before You (Nashville, TN: B\&H, 2018).]

\section{Right Judgments, Right Offerings, and Right Testimony in Deuteronomy}

\begin{tabular}{|c|c|c|}
\hline $\begin{array}{l}\text { Key } \\
\text { Theme }\end{array}$ & $\begin{array}{l}\text { Deuteronomy 16:18-17:13 } \\
\text { Judges and Priests }\end{array}$ & $\begin{array}{l}\text { Deuteronomy 17:14-18:22 } \\
\text { Kings, Priests, and Prophets }\end{array}$ \\
\hline $\begin{array}{l}\text { Right } \\
\text { Judgments }\end{array}$ & $\begin{array}{l}\text { 'Appoint judges and officials... in all } \\
\text { the towns the LORD your God is } \\
\text { giving you... Pursue justice and justice } \\
\text { alone so that you will live and possess } \\
\text { the land' (16:18-20). } \\
\text { Three prohibitions: 'Do not deny justice } \\
\text { or show partiality to anyone. Do not } \\
\text { accept a bribe' (16:19). }\end{array}$ & $\begin{array}{l}\text { 'When you enter the land the LORD } \\
\text { your God is giving you, take posses- } \\
\text { sion of it, live in it' (17:14). } \\
\text { Three prohibitions: 'He must not acquire } \\
\text { many horses... He must not acquire } \\
\text { many wives... He must not acquire } \\
\text { very large amounts of silver and gold' } \\
\text { (17:16-17). } \\
\text { Instructions for the king in contrast to 'the } \\
\text { man who acts arrogantly' (17:11-13): 'He } \\
\text { is to write a copy of this instruction... } \\
\text { so that he may learn to fear the LORD } \\
\text { his God, to observe all the words of } \\
\text { this instruction... He will not turn } \\
\text { from this command to the right or the } \\
\text { left' (17:18-20). }\end{array}$ \\
\hline $\begin{array}{l}\text { Right } \\
\text { Offerings }\end{array}$ & $\begin{array}{l}\text { 'You must not sacrifice to the LORD } \\
\text { your God an ox or sheep with a defect } \\
\text { or any serious flaw' }(17: 1) \text {. }\end{array}$ & $\begin{array}{l}\text { 'This is the priests' share from the } \\
\text { people who offer a sacrifice, whether } \\
\text { it is an ox, a sheep' }(18: 3)\end{array}$ \\
\hline
\end{tabular}




\begin{tabular}{|c|c|c|}
\hline $\begin{array}{l}\text { Key } \\
\text { Theme }\end{array}$ & $\begin{array}{l}\text { Deuteronomy 16:18-17:13 } \\
\text { Judges and Priests }\end{array}$ & $\begin{array}{l}\text { Deuteronomy 17:14-18:22 } \\
\text { Kings, Priests, and Prophets }\end{array}$ \\
\hline $\begin{array}{l}\text { Right } \\
\text { Testimony }\end{array}$ & $\begin{array}{l}\text { 'If a man or woman among you in one } \\
\text { of your gates that the LORD your } \\
\text { God will give you... has gone to wor- } \\
\text { ship other gods... you must investi- } \\
\text { gate... If the report turns out to be } \\
\text { true that this detestable thing has } \\
\text { happened in Israel... stone them to } \\
\text { death' (17:2-5). } \\
\text { 'According to the terms of the instruc- } \\
\text { tion which they teach you shall do; } \\
\text { you shall not turn aside from the word } \\
\text { which they declare to you to the right } \\
\text { or the left' (17:11 NASB). } \\
\text { 'The man who acts [arrogantly]... } \\
\text { shall die... Then all the people will } \\
\text { hear and be afraid, and will not act } \\
\text { [arrogantly] again' (17:12-13 NASB). }\end{array}$ & $\begin{array}{l}\text { 'When you enter the land the LORD } \\
\text { your God is giving you, do not imitate } \\
\text { the detestable customs of those na- } \\
\text { tions... Everyone who does these } \\
\text { things is detestable to the LORD' } \\
(18: 9,12) \text {. } \\
\text { 'The prophet who [arrogantly } \\
\text { speaks]—-that prophet must die... } \\
\text { When... the [word] does not come } \\
\text { true... the prophet has spoken it [ar- } \\
\text { rogantly]. Do not be afraid of him' } \\
(18: 20-22) \text {. }\end{array}$ \\
\hline
\end{tabular}

\section{Bibliography}

Allender D (2006) Leading with a Limp: Take Full Advantage of Your Most Powerful Weakness. Colorado Springs, CO: Waterbrook Press.

Attridge H (1989) The Epistle to the Hebrews. Philadelphia, PA: Fortress Press.

Beale GK (2011) A New Testament Biblical Theology. Grand Rapids, MI: Baker Academic Press.

Beckman G (1996) Hittite Diplomatic Texts. Atlanta, GA: Scholars Press.

Blenkinsopp J (1995) Sage, Priest, Prophet. Louisville, KY: Westminster John Knox Press.

Block D (2005) The Burden of Leadership: The Mosaic Paradigm of Kingship (Deuteronomy 17:14-20). Bibliotheca Sacra 162(647): 259-278.

Bonhoeffer D (1954) Life Together. Trans. Doberstein JW (ed) New York: Harper Books.

Cafferky M (2010) Honor the King. Yes, But Emulate the King? Journal of Applied Christian Leadership 4(2): 32-51.

Calvin J (1559), Institutio Christianae religionis, 2:15.

Carson DA (2007) 1 Peter. In Carson DA and Beale GK (eds) Commentary on the New Testament Use of the Old Testament. Grand Rapids, MI: Baker Academic Press. Pages 1015-1045.

Catechism of the Catholic Church (1581).

Cheong R (2012) God Redeeming His Bride: A Handbook for Church Discipline.

Kindle edition. Fearn: Christian Focus Publications. 
Costecalde C-B (1986) Aux Origines du Sacre Biblique. Paris: Letouzey and Ane.

Covrig D, Ongo M, and Ledesma J (2012) Integrating Four Types of Moral Leadership. Journal of Applied Christian Leadership 6(*): 36-63.

Craigie P (1976) The Book of Deuteronomy. Grand Rapids, MI: Eerdmans Publishing.

Crouse R (2015) Church as Priest, King, Prophet. Presentation at Evangelical Theological Society Annual Meeting, Atlanta, GA.

Diffey D (2011) The Royal Promise in Genesis: The Often Underestimated Importance of Genesis 17:6, 17:16, and 35:11. Tyndale Bulletin 62(2): 313-316.

Dogmatic Constitution on the Church (1964). Lumen Gentium.

Driscoll M (2008) On Church Leadership. Wheaton, IL: Crossway Publishing.

Durham JI (1987) Exodus. Waco, TX: Thomas Nelson Publishers.

Ellingworth P (1993) The Epistle to the Hebrews. Grand Rapids, MI: Eerdmans Publishing.

Eusebius of Caesarea, Historia ecclesiastica 1:3:8.

Fairchild D (2008) Prophet, Priest, and King Acts 29 Bootcamp. Raleigh, NC.

Fernando A (2012) Deuteronomy: Loving Obedience to a Loving God. Wheaton, IL: Crossway Books.

First London Confession of Faith (1644).

Frame J (2008) A Primer on Perspectivalism. Available from: http://www.frame-poythress.org. [Accessed 12 March 2017].

Goodmanson (2008) Triperspectival Leadership. Acts 29 Bootcamp. Raleigh, NC.

Goodmanson D (2006) How Multiperspectivalism Shapes Church Leadership and How You Staff a Church. Available at: http://www.goodmanson.com. [Accessed 12 March 2017].

Goswell G (2011) Isaiah 1:26: A Neglected Text on Kingship. In Tyndale Bulletin 62(2): 233-246.

Greggs T (2015) The Priesthood of No Believer: On the Priesthood of Christ and His Church. In International Journal of Systematic Theology 17(4): 374-398.

Grundmann W (1964) Chrio. In Kittel G and Friedrich G (eds) and Bromiley G (trans) Theological Dictionary of the New Testament, volume 9, Grand Rapids, MI: Eerdmans Publishing. Pages 493-580.

Heidelberg Catechism (1563).

Hughes PE (1977) A Commentary on the Epistle to the Hebrews. Grand Rapids, MI: Eerdmans Publishing.

Jobes K (2005) 1 Peter. Grand Rapids, MI: Baker Book Publishing.

Jones TP (2017) The God Who Goes Before You. Nashville, TN: Broadman \& Holman Publishers. 
Kaiser W (2008) Exodus. In Garland D and Longman T (eds) The Expositor's Bible Commentary, volume 1, revised edition. Grand Rapids, MI: Zondervan Publishing. Pages 333-562.

Kalland E (1992) Deuteronomy. In Garland D and Longman T (eds) The Expositor's Bible Commentary. volume 3 Grand Rapids, MI: Zondervan Publishing, 457-814.

Keener C (2013) Acts: An Exegetical Commentary. volume 2, Kindle edition. Grand Rapids, MI: Baker.

Kline M (1997) The Structure of Biblical Authority, second edition. Eugene, OR: Wipf and Stock Publishers.

Klouda S (2000) The Dialectical Interplay of Seeing and Hearing in Psalm 19 and Its Connection to Wisdom. Bulletin for Biblical Research 10(2): 181195.

Leeman J (2012) Church Discipline. Wheaton, IL: Crossway Publishing.

Leithart P (2003) A Son to Me. Kindle edition. Moscow, ID: Canon Press.

Levinson B (2001) The Reconceptualization of Kingship in Deuteronomy and the Deuteronomistic History's Transformation of Torah. Vetus Testamentum 51(4): $511-534$.

Luther M (1961) Lectures on Romans. Pauck W (ed) Philadelphia, PA: Westminster Press.

Macaskill G (2014) Union with Christ in the New Testament. Oxford: Oxford University Press.

Manly Jr B (1859) The Abstract of Principles of The Southern Baptist Theological Seminary.

Martinez F (2000) Las tradiciones sobre Melquisedec en los manuscritos de Qumran. Biblica 81(*): 70-80.

McCarthy D (1965) 2 Samuel 7 and the Structure of Deuteronomistic History. Journal of Biblical Literature 84(2): 131-138.

Moo D (1985) James. Leicester: InterVarsity Press.

Moo D (1996) Epistle to the Romans. Grand Rapids, MI: Eerdmans Publishing.

Norman L (1972) The Great American Novel. Only Visiting This Planet. Verve Records.

O'Brien PT (2010) The Letter to the Hebrews. Grand Rapids, MI: Eerdmans Publishing.

Peterson R (2015) Salvation Applied by the Spirit. Wheaton, IL: Crossway Publishing.

Poythress V (1996) Modern Spiritual Gifts as Analogous to Apostolic Gifts: Affirming Extraordinary Works of the Spirit within Cessationist Theology. Journal of the Evangelical Theological Society 39(1): 71-101.

Pritchard J (ed) (1969) Ancient Near Eastern Texts Relating to the Old Testament, third edition. Princeton, NJ: Princeton University Press. 
Robson J (2011) Forgotten Dimensions of Holiness. Horizons in Biblical Theology 33(*): 121-146.

Schreiner T (1998) Romans. Grand Rapids, MI: Baker Book Publishing.

Stevens M (2012) Leadership Roles of the Old Testament: King, Prophet, Priest, Sage. Eugene, OR: Wipf and Stock Publishers.

Sweeney M (2007) 1 and 2 Kings. Louisville, KY: Westminster John Knox Press.

Thiselton A (2000) The First Epistle to the Corinthians. Grand Rapids, MI: Eerdmans Publishing.

Tidball D (1986) Skillful Shepherds: An Introduction to Pastoral Theology, Grand Rapids, MI: Zondervan Publishing.

Tigay J (1996) Deuteronomy. Philadelphia, PA: Jewish Publication Society.

Timmis S (2012) Gospel Centered Leadership. Epsom: Good Book Company.

Vieth V and Tchividjian B (2015) When the Child Abuser Has a Bible: Investigating Child Maltreatment Sanctioned or Condoned by A Religious Leader. Available from: http://www.netgrace.org [Accessed: 12 March 2017]

Wainwright G (1997) For Our Salvation. Grand Rapids, MI: Eerdmans Publishing.

Westminster Confession of Faith (1646).

Westminster Larger Catechism (1647).

Westminster Shorter Catechism (1647).

Woodhouse J (2008) 1 Samuel: Looking for a Leader. Wheaton, IL: Crossway Publishing.

Wright NT (2002) Romans. In Keck L (ed) The New Interpreter's Bible. Nashville, TN: Abingdon. 